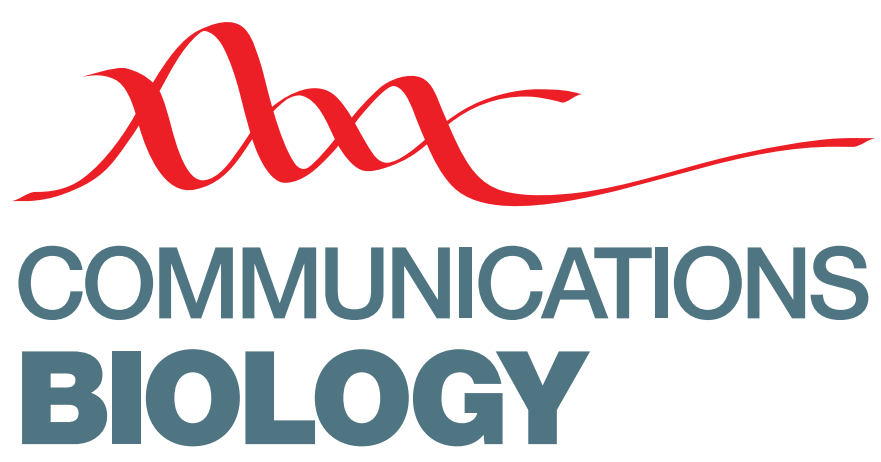

Check for updates

https://doi.org/10.1038/s42003-020-01292-7 OPEN

\title{
Author Correction: Nrf2 contributes to the weight gain of mice during space travel
}

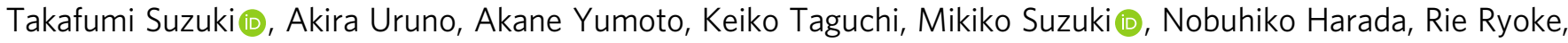
Eriko Naganuma, Nanae Osanai, Aya Goto, Hiromi Suda, Ryan Browne, Akihito Otsuki (D), Fumiki Katsuoka,

Michael Zorzi @, Takahiro Yamazaki, Daisuke Saigusa, Seizo Koshiba, Takashi Nakamura @i, Satoshi Fukumoto, Hironobu Ikehata, Keizo Nishikawa, Norio Suzuki, Ikuo Hirano, Ritsuko Shimizu, Tetsuya Oishi, Hozumi Motohashi D, Hirona Tsubouchi, Risa Okada, Takashi Kudo, Michihiko Shimomura, Thomas W. Kensler (1), Hiroyasu Mizuno, Masaki Shirakawa, Satoru Takahashi@, Dai Shiba \& Masayuki Yamamoto (1)

Correction to: Communications Biology https://doi.org/10.1038/s42003-020-01227-2, published online 08 September 2020.

In the originally published version of the Article, an incorrect file was uploaded as Supplementary Movie 1. The error has been corrected in the HTML version of the Article.

Published online: 07 October 2020

\footnotetext{
(c) Open Access This article is licensed under a Creative Commons Attribution 4.0 International License, which permits use, sharing, adaptation, distribution and reproduction in any medium or format, as long as you give appropriate credit to the original author(s) and the source, provide a link to the Creative Commons license, and indicate if changes were made. The images or other third party material in this article are included in the article's Creative Commons license, unless indicated otherwise in a credit line to the material. If material is not included in the article's Creative Commons license and your intended use is not permitted by statutory regulation or exceeds the permitted use, you will need to obtain permission directly from the copyright holder. To view a copy of this license, visit http://creativecommons.org/licenses/by/4.0/.
}

(C) The Author(s) 2020 